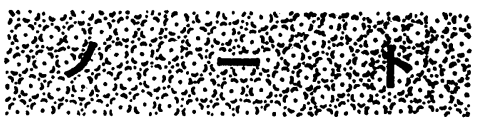

\title{
腸内細菌及び緑膿菌によるニトロソアミンの分解
}

(昭和 61 年 7 月 15 日受理)

\author{
中 浜隆之* 浦久保五郎*

\section{Degradation of $N$-Nitrosamines by Enteric Bacteria and Pseudomonas aeruginosa}

\section{Takayuki NAKAHAMA and Goro URAKUBO}

(School of Pharmaceutical Science, Toho University: 2-1

Miyama 2, Funabashi-shi, Chiba Prefecture, Japan)

\begin{abstract}
Degradation of diphenylnitrosamine (DPN), diethylnitrosamine (DEN), and $t$-butylethylnitrosamine $(t$-BEN) by several kinds of enteric bacteria was investigated and the following results were obtained.

1) The degradation rates of DPN and DEN by 5 kinds of enteric bacteria during a 24 -hour incubation were $66 \sim 90 \%$ (control, 15\%) and $4 \sim 16 \%$ (control, $2 \%$ ), respectively.

2) In experiments with Pseudomonas aeruginosa under the same conditions, $85 \%$ (control, not degraded) of DPN and 18\% (control, $8 \%$ ) of DEN were degraded, but $t$-BEN was practically not degraded.

3) It was found that $84 \%$ (control, $8 \%$ ) of DPN and $31 \%$ (control, $11 \%$ ) of DEN were degraded by bacteria extracted from the cecal content of guinea pig, but $t$-BEN was not degraded under the same conditions.
\end{abstract}

(Received July 15, 1986)

Key words: ニトロソアミン nitrosamine; 縁膿菌 Pseudomonas aeruginosa; 腸内細菌 enteric bacteria; ジフェニルニトロソアミン diphenylnitrosamine; ジェチルニトロソアミン diethyl. nitrosamine; $t$-ブチルェチルニトロソアミン $t$-butylethylnitrosamine

\section{まえがき}

ニトロソアミン (NA) がほ乳動物の体内で第二アミン から生成されることは知られているが，第二アミンと亜 硝酸を加えた培地中で E. coli, P. vulgaris など数種の 微生物により生成を触媒されるという報告1) ある。 ま た逆に in vitro 実験でジフェニルニトロソアミン, $N$. ニトロソピロリジン, ジメチルニトロソアミンが $E$. coli, Lactobacillus などの腸内細菌により分解されると いう報告2) るみられる.

* 東邦大学薬学部：千葉県船橋市三山 2-2-1
本報では，異なった置換基をもつ NA としてフェニ ル基をもつジフェニルニトロソアミン $(\mathrm{DPN})$, 直鎖置換 基のジェチルニトロソアミン $(\mathrm{DEN})$, 及び分枝置換基の

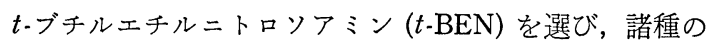
腸内細菌菌株が増殖する過程で NA が分解する程度を 調べた。また，ある種の緑膿菌は，常在の腸内細菌では 分解されにくい化合物でも分解する場合があることか ら，特に緑膿菌について詳しく調べ，更に混合菌の相乗 作用の例として盲腸内細菌を選び NA が時間とともに どのように分解するかを調べた結果を報告する。 


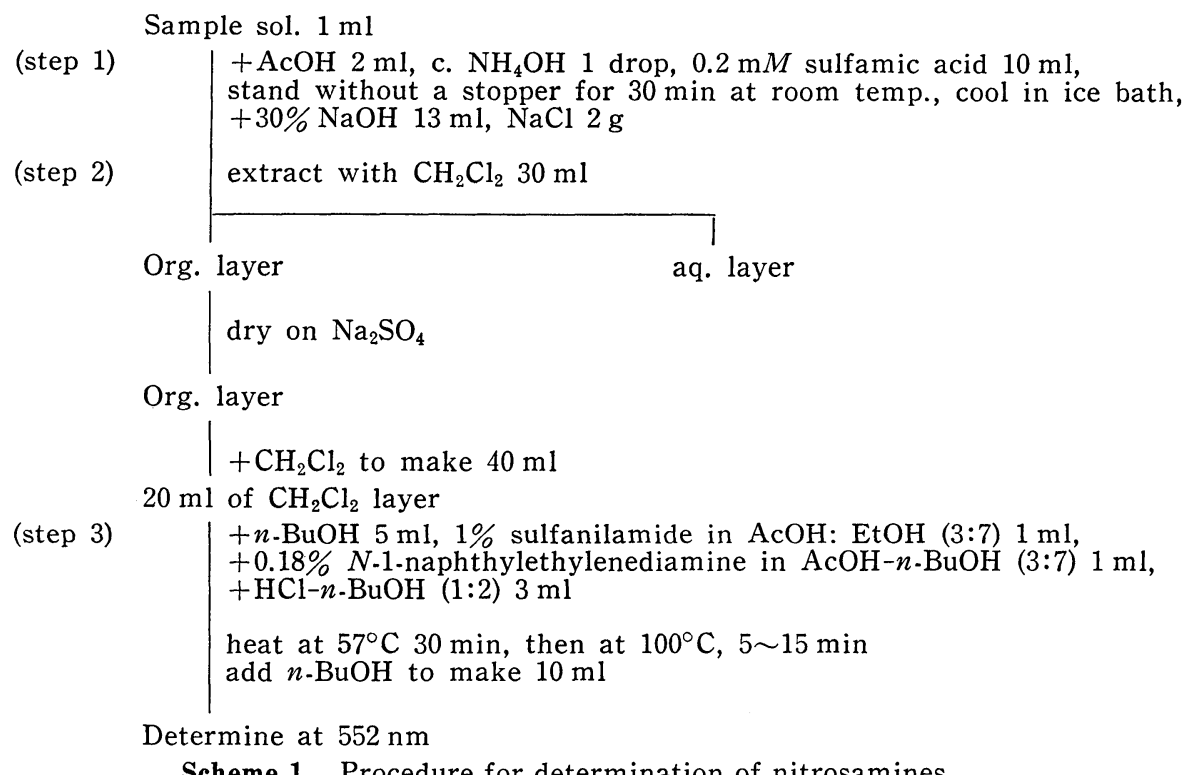

\section{実験方法}

\section{1. 試薬及び装置}

スルファニルアミド：特級（小宗化学薬品）

$N$-1-ナフチルエチレンジアミン (二塩酸塩) : 特級 (小 宗化学薬品)

スルファミン酸：特級（小宗化学薬品）

酢酸：特級（小宗化学薬品）

塩酸：特級（小宗化学薬品）

硫酸ナトリウム (無水)：1級 (小宗化学薬品)

塩化ナトリウム: 特級（小宗化学薬品）

ジクロロメタン: 特級（小宗化学薬品）

$n$-ブタノール：特級（小宗化学薬品）

アンモニア水: 1 級 (小宗化学薬品)

ジフェニルニトロソアミン: (東京化成工業)

ジェチルニトロソアミン: (東京化成工業)

$t$-ブチルエチルニトロソアミン: (東京化成工業)

普通ブイヨン: (栄研化学)

振とう機: Recipro Shaker SR-II (大洋科学)

分光光度計: Spectronic 20 A (島津製作所)

遠心分離機: M-160 型(佐久間)

2. 培養液中の NA の定量法

1) 定量法

NA の定量は, 伊藤ら ${ }^{3)}$ の報告した食品中の第二アミ

ンと NA の総量の定量方法すなわち第二アミンを NA

に変え, NA の総量を再び分解して生成する亜硝酸を常 法により比色定量する方法を培地中の NA だけを定量 するように簡略化して行った.

$50 \mathrm{ml}$ ネスラー管に酢酸 $2 \mathrm{ml}, 0.2 \mathrm{~m} M$ スルファミン 酸溶液 $10 \mathrm{ml}$, 精製水 $1 \mathrm{ml}$ を取り, アンモニア水 1 滴
を加えて $\mathrm{pH}$ を 2 とした液中に $\mathrm{NA}$ を含さ試料溶液 1 $\mathrm{ml}$ を加え, 亜硝酸が窒素として十分に放出除去される ように開栓したまま室温で30分間放置した。次に氷冷下 $30 \%$ 水酸化ナトリウム $13 \mathrm{ml}$ と塩化ナトリウム $2 \mathrm{~g}$ を 加えて溶解し, 蒸留により精製したジクロロメタン 30 $\mathrm{m} 1$ を加えて分液漏斗中で10分間機械振とうして抽出を 行った. 抽出混液を $2,000 \mathrm{rpm} 5$ 分間遠心分離して, ジ クロロメタン層を分取した. 得られたジクロロメタン層 に硫酸ナトリウムを加えて脱水し, 上清を $50 \mathrm{ml}$ 共栓 メスシリンダに傾斜して移し，ジクロロメタンを加えて 正確に $40 \mathrm{ml}$ とした. 混和後 $20 \mathrm{ml}$ を分取し, 遠沈管に 移し， $n$-ブタノール $5 \mathrm{ml}, 1 \%$ スルファニルアミドの $30 \%$ 酢酸-エタノール溶液 $1 \mathrm{ml}, 0.18 \% \mathrm{~N}-1$-ナフチル エチレンジアミンの $30 \%$ 酢酸-ブタノール溶液 $1 \mathrm{ml}$, 塩酸-ブタノール (1:2) 混液 $3 \mathrm{ml}$ を加えて, $57^{\circ}$ の恒 温槽中で30分間加温した. その後 $100^{\circ}$ の沸騰水浴中に 浸し, DPN と $t$-BEN の場合は 5 分間, DEN の場合 は15分間加熱して呈色させた。放冷した後, 濃縮された 混液に $n$-ブタノールを加えて $10 \mathrm{ml}$ とした溶液につい て $552 \mathrm{~nm}$ における吸光度を測定した. なお対照には試 料 $1 \mathrm{ml}$ の代りに合成培地を用いて同様の操作を施した ものを用いた. 定量法の概略を Scheme 1 に示す.

2) 振とう時間の検討

定量法 (Scheme 1, Step 2) において NA のジクロ ロメタン抽出を機械振とらにより行ったが，振とう時間 による抽出量への影響について DPN を用いて実験し た. 他の条件はすべて同様にし，振とう時間を $3 ， 5$, $10,15,20$ 分間と変えて吸光度を比較した. 
3）加熱時間の検討

定量法の最終操作 (Scheme 1, Step 3) のカップリン グによる呈色を比色測定する際の検液の吸光度は, 加熱 時間により影響を受けることが見られた. それぞれの最 大值を知るため， $100^{\circ}$ での加熱時間を $5,10 ， 15 ， 20$, 25分間と変えて吸光度を比較した。

4) 検量線

DPN， DEN， $t$-BEN のそれぞれ $1 \mathrm{mmol}$ (DPN $198 \mathrm{mg}$, DEN $102 \mathrm{mg}, t$-BEN $130 \mathrm{mg})$ に DMSO を加 えて溶かし， $200 \mathrm{ml}$ とした.この液に後記の 合成培地 を加えて $1 \mu \mathrm{mol} / \mathrm{ml}$ に薄めたものを原液とした．原液 を段階的に薄めた液 $1 \mathrm{ml}$ をとり, NA の定量法に従っ て操作を行った.

\section{3. 諸種菌株による NA の分解}

菌株には一般的な腸内細菌を主として次に示す 5 種の 株を用いた. Escherichia coli ATCC 8739 (E. coli), Proteus vulgaris sp. (Prot. vul.), Citrobacter freundii ATCC 8090 (Cit. freu.) Pseudomonas aeruginosa ATCC 9027 (Pseud. aer.), Klebsiella pneumoniae ATCC 8329 (Kleb. pneu.). 斜面培養からコロニー1 白 金耳ずつを取り，普通ブイヨン $15 \mathrm{ml}$ を入れた試験管 中に植え継ぎ， $37^{\circ} ， 24$ 時間培養した. 各菌の培養液 $10 \mathrm{ml}$ ずつを取り, 普通ブイヨン $300 \mathrm{ml}$ を入れた三角 フラスコ内へ植え継ぎ, $37^{\circ}, 24$ 時間振とう培養した. 各培養液 $300 \mathrm{ml}$ を $3,800 \times \mathrm{g}, 10$ 分間遠心分離し, 沈降 した菌体を生理食塩水で 2 回懸濁洗浄を行い, 生理食塩 水を加えて一定量とし菌数を測定したものを各々の菌原 液とした。な打菌数の測定には，この菌原液を生理食塩 水で一定量に希釈して $420 \mathrm{~nm}$ の吸光度を測定し, 常法 により吸光度と生菌数との関係から菌数を算定した.

分解実験には次の組成の合成培地を用いた.リン酸水 素二カリウム $70 \mathrm{~g}$, リン酸二水素カリウム $30 \mathrm{~g}$, クエン 酸ナトリウム (二水塩) $5 \mathrm{~g}$, 硫酸マグネシウム (七水塩) $1 \mathrm{~g}$, 硫酸アンモニウム $10 \mathrm{~g}$, カサミノ酸 $10 \mathrm{~g}$, ブドウ糖 $2 \mathrm{~g}$, 硫酸第一鉄 (七水塩) $0.25 \mathrm{mg}$, 硫酸亜鉛 (七水塩) $0.25 \mathrm{mg}$, 硫酸マンガン (三水塩) $0.25 \mathrm{mg}$, 塩化カルシ ウム $10 \mathrm{mg}$ を精製水に溶かして $1 \mathrm{~L}$ とし， pH 7.1 に 調整した。

DPN と DEN の DMSO 溶液をそれぞれ $0.25 \mathrm{mM}$ となるように添加した合成培地 $200 \mathrm{ml}$ を $300 \mathrm{ml}$ の三 角フラスコにとり，あらかじめ調製した 5 種の菌原液の 希釈懸濁液を総菌数約 $10^{8}$ 個を含むように加えた。ただ ちに $37^{\circ}$ で振とう培養を行い，0，12，24 時間後の培養 液 $5 \mathrm{ml}$ ずつ採取し， $2^{\circ}, 3,800 \times \mathrm{g}, 10$ 分間遠心分離を 行った. 上清 $1 \mathrm{ml}$ を試料溶液として用いて以下 Scheme 1 に従ってNA の定量を行った. なお, DPN と DEN を含み菌を加えず振とらした培地を対照として用いた。

\section{4. 緑膿菌による NA の分解}

$\mathrm{DPN}, \mathrm{DEN}, t$-BEN を用い，それぞれの DMSO 溶液
を最終濃度 $50 \mathrm{mg} / \mathrm{L}$ となるように合成培地中に添加し, 次に約 $10^{8}$ 個の Pseud. aer. を含むよらに菌懸濁液を添 加した.ただちに $37^{\circ}$ で振とう培養を行い，0，3，6， 12，18，24時間後に培養液 $5 \mathrm{ml}$ を採取し， $2^{\circ}, 3,800 \times$ $\mathrm{g}, 10$ 分間遠心分離を行った. その上清 $1 \mathrm{ml}$ を試料溶 液として用いて, 以下 Scheme 1 に従って NA の定量 を行った.なお，NA を含み菌を加えす゚に振とうした培 地を対照として用いた。

\section{5. モルモット盲腸内細菌による NA の分解}

Hartley 系雄モルモット（体重 300～400 g) 1 匹から 盲腸内容物 $2 \mathrm{~g}$ を取り生理食塩水 $100 \mathrm{ml}$ に加え10分間 機械振とうした。その眯濁液を綿ろ過し，ろ液を 1,000 $\mathrm{rpm}$ で 5 分間遠心分離した. 上清 $20 \mathrm{ml}$ を取り, 普通 ブイヨン $200 \mathrm{ml}$ に加え, $37^{\circ}$, 24時間静置培養を行い $3,800 \times \mathrm{g}, 10$ 分間遠心分離し, 沈降した菌体を生理食塩 水で懸濁洗浄を行い菌原液を得た. 以降の分解実験には $\mathrm{DPN}, \mathrm{DEN}, t$-BEN を用い前記の 緑膿菌の場合と同じ 操作を行った.

\section{実験 結 果}

\section{1. 培養液中の NA の定量法}

1) 振とら時間の検討

振とう時間による抽出量への影響についての実験結果 を Fig. 1 に示す. 10分から15分の間にピークがあり， この間に変化が見られなかったので, 抽出のための振と

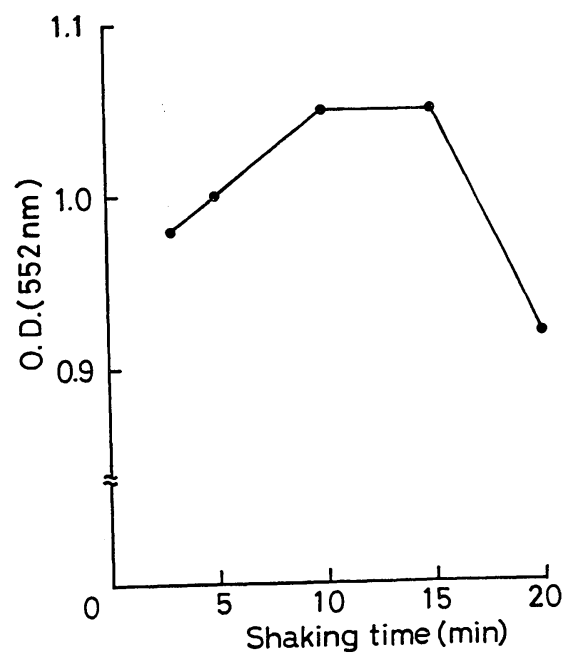

Fig. 1. Relationship between optical density of final reaction mixture and shaking time for extraction with dichloromethane

The reaction mixture described in step 1 of Scheme 1 was extracted with $30 \mathrm{ml}$ of dichloromethane by shaking for 5,10 , 15 , or $20 \mathrm{~min}$. Diphenylnitrosamine $(0.5$ $\mathrm{m} M$ ) were used as a sample solution. 


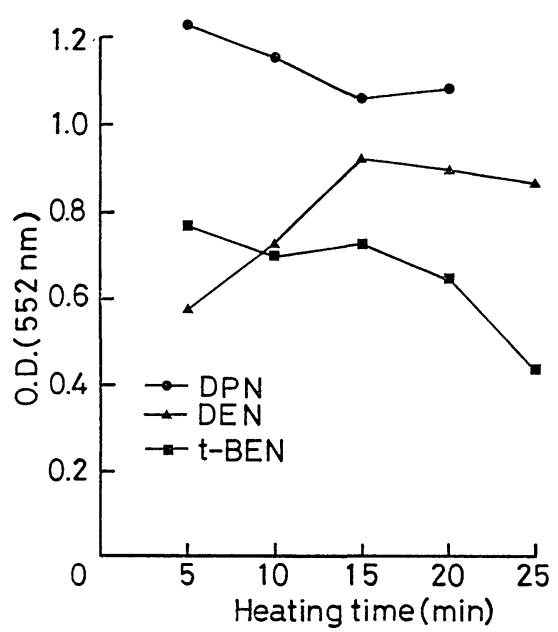

Fig. 2. Relationship between optical density of final reaction mixture and heating time at $100^{\circ} \mathrm{C}$

The reaction mixture described in step 3 of Scheme 1 was heated at $57^{\circ} \mathrm{C}$ for $30 \mathrm{~min}$ and then at $100^{\circ} \mathrm{C}$ for $5,10,15,20$, or $25 \mathrm{~min}$. Nitrosamines $(0.5 \mathrm{mM})$ were used as sample solutions.

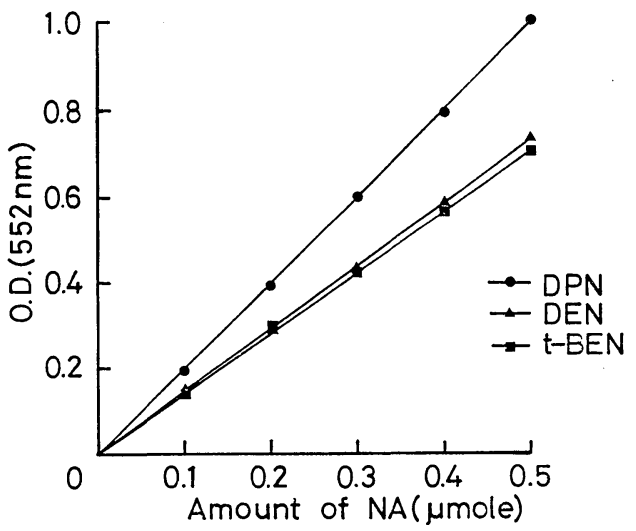

Fig. 3. Calibration curves of nitrosamines, obtained in determination of DPN, DEN and $t$-BEN by procedure shown in Scheme 1

う時間は10分間とした。

2) 加熱時間の検討

加熱時間の吸光度への影響についての実験結果を

Fig. 2 に示す. 以後の定量には, 呈色の最大值をとって $\mathrm{DPN}$ と $t$ - BEN の加熱時間は 5 分間, DEN は15分間と した.

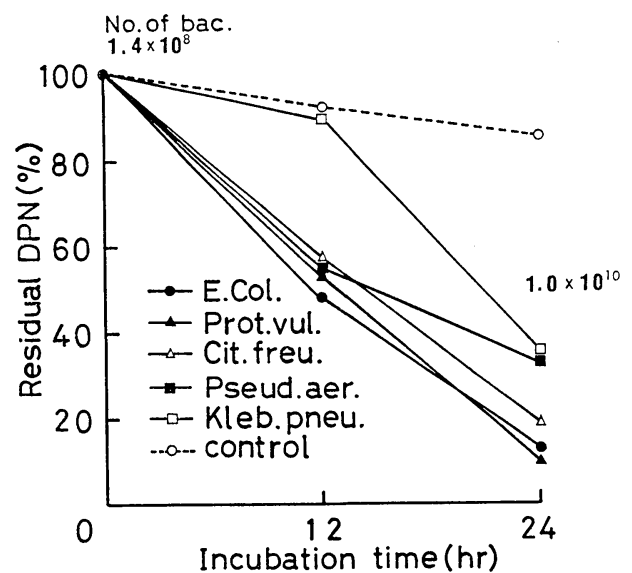

Fig. 4. Degradation of DPN by 5 strains of enteric bacteria after incubation of the media containing these strains and 0.25 $\mathrm{m} M \mathrm{DPN}$

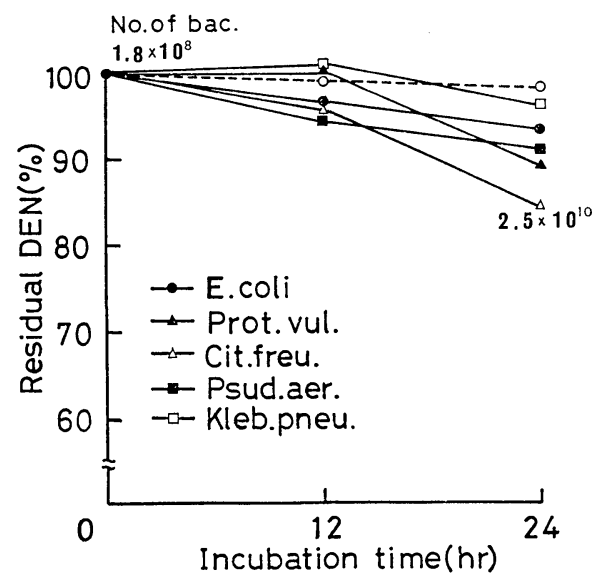

Fig. 5. Degradation of DEN by 5 strains of enteric bacteria after incubation of the media containing these strains and 0.25 $\mathrm{m} M \mathrm{DEN}$

3) 検量線

各濃度の NA Scheme 1 の試料の代りに用い定量 操作を行い得られた検量線を Fig. 3 に示す.

2. 5 種の菌株の比較について

5 種の菌株による DPN 及び DEN の分解結果をそれ ぞれ Fig. 4, Fig. 5 に示す.

各菌株による DPN の24時間後の分解率は, 対照実験 で 15\%，菌を加えたとき Prot. vul. 90\%，E. coli 87\%, Cit. freu. 81\%, Pseud. aer. 66\%, Kleb. Pneu. $66 \%$ の分解を示し, 菌株による大きな差は見られなか った.また DEN の24時間後の分解率は, 対照実験で $2 \%$ ，菌を加えたときCit. freu. 16\%, Prot. vul. 12\%， 


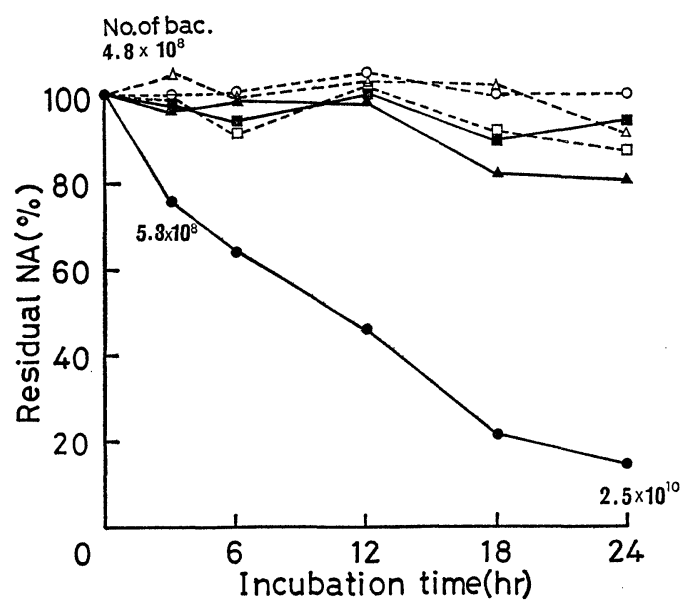

Fig. 6. Degradation of nitrosamines by Pseud. aer. after each interval during incubation of the media containing $50 \mathrm{mg} / \mathrm{L}$ $\mathrm{DPN}, \mathrm{DEN}$ and $t$-BEN
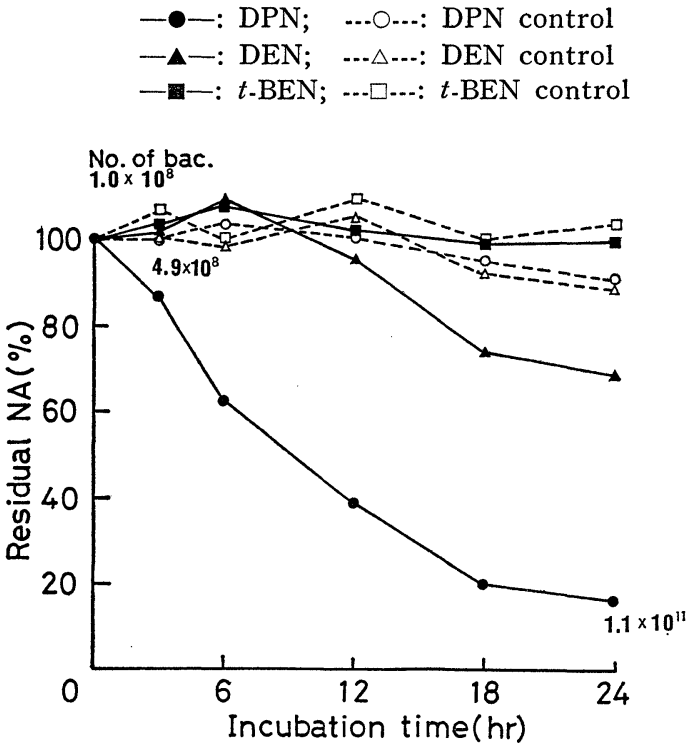

Fig. 7. Degradation of nitrosamines by bacteria in cecal content after each interval during incubation of media containing $50 \mathrm{mg} / \mathrm{L}$ DPN, DEN and $t$-BEN

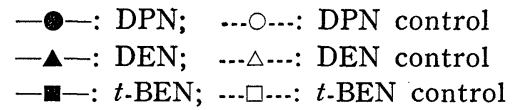

Pseud.aer. 9\%, E. coli 7\%, Kleb. pneu. 4\% であり, Cit. freu. では他の菌株に較べて分解率が高かったが, 一般に DPN に較べて分解率は著明に低かった。

\section{3. 緑膿菌について}

Pseud. aer.を用いて，培養24時間まで 6 回測定した
NA の分解結果を Fig. 6 に示す. DPN については, 対 照実験で分解しなかったが，菌体を加えたときは培養時 間の経過によりほとんど直線状に分解が進み 24 時間で 85\% が分解された. DEN の分解率については24時間で 対照は $8 \%$ ，菌体を加えたとき $18 \%$ であった。 た $t$-BEN の分解率は対照で $8 \%$, 菌体を加えたとき $5 \%$ で，菌による分解が認められなかった。

\section{4. 盲腸内細菌について}

モルモット盲腸内細菌による NA の分解結果を Fig. 7 に示す. DPN の 24 時間後の分解率は対照実験で $8 \%$ ，菌体を加えたとき $84 \%$ であった． DEN の24時間 後の分解率は対照で $11 \%$ ，菌体を加えたとき $31 \%$ であ ったが， $t$-BEN は分解が認められなかった。

\section{考察}

5 種の菌株による NA の分解実験では，いずれの菌株 の場合にも DPN は DEN より大きな分解率を示した. それぞれの NA の分解率は菌株の 種類によって大きな 差はなく，いくらか見られる差異は菌の種類による増殖 の相違に基づくものと考えられる.Pseud. aer. 及び盲 腸内細菌による分解実験の 結果では, DPN がよく分解 され，DEN の分解よりも著明な差がみられた. Rowland ら $^{2)}$ は, NA の本実験濃度の $1 / 5$ すなわち $0.05 \mathrm{~m} M$ 以下の希薄な濃度で, 腸内細菌により DPN が $N$-ニト ロソピロリジン及びジメチルニトロソアミンよりもはる かに速く分解されることを報告しているが，本実験の結 果も一致している. しかし，盲腸内細菌による分解実験 では, DPN の分解では Pseud. aer. の場合よりも分解 率が低いにもかかわらず，DEN では，より高い分解率 を示した。 これは，盲腸内細菌のらちに DENをよりよ く分解する菌株が含まれていたものと思われ，菌の種類 により分解されやすい NA が異なるというような特異 性があることが示唆される.

本実験では，異なった置換基をもつ NA として $\mathrm{DPN}, \mathrm{DEN}$ 及び $t$-BEN の 3 種を用いた結果として, DPN は菌により著しく分解し, DEN も多少の分解が 見られたが， $t$-BEN では分解が認められなかった． 細菌 による化合物の分解作用は通常加水分解または還元によ るものであることがよく知られて拈り, ${ }^{4)}$, 一方本実験の 定量法では 决-N= 結合の開裂をみているが，定量法の 加熱時間の検討 (Fig. 2) では NA の分解により生じた 亚硝酸による吸光度が最大を示す時間は, DPN と $t$ BEN では 5 分間, DEN は15分間で, 3 者のらちでは比 較的熱に安定な化合物であると考えられる．従って， DPN は熱にも生物的にも分解されやすく, DEN と $t$ $\mathrm{BEN}$ を比較すると, DEN は $t$-BEN よりも化学的には 安定であるが，生物的には分解されやすいといえる。

以上のように置換基の相違により，>N-N= 結合の細 菌に対する抵抗性に相違がみられ，t-BEN が DEN よ りも細菌により分解されにくいのは置換基が分枝してい 
るためであろらと推察されるが, 詳しくは今後の検討を 要する.

なお本実験は好気的条件のみで行ったため，実際のほ 乳動物の腸内では，嫌気的条件が大きな割合を占めると 思われ，NA の分解は今回の実験結果と同様の傾向を示 すかどらかは疑問であり，今後の検討を要する. しかし， DPN などの分解されやすいNA がもし体内に導入され ると, 消化管で分解されてから吸収されることが多く, 比 較的分解されにくいNA はそのままの形で吸収される ものと考えられる. 従って, 腸内に存在する細菌の種類 と量の違いにより，体内に導入された NA の作用が影 響を受けると思われる。

\section{結語}

本報告では, 3 種のニトロソアミンを用いて, 数種の 腸内細菌による分解の程度を調べた.

1） 5 種の菌株による DPN の分解率は，24時間の培 盖で対照実験 15\%，菌体を加えたとき 66〜90\% であ り，DEN は対照で $2 \%$ ，菌体を加えたとき 4〜16\%で
あった。

2. Pseud. aer. による同条件の DPN の分解率は対 照実験では分解せず，菌体を加えたとき $85 \%$ であり， DEN は対照で 8\%，菌体を加えたとき $18 \%$ であった が， $t$-BEN は分解されなかった.

3. モルモットの盲腸内細菌による同条件の $\mathrm{DPN}$ の 分解率は対照で $8 \%$ ，菌体を加えたとき $84 \%$ であり， $\mathrm{DEN}$ は対照で $11 \%$ ，菌体を加えたとき $31 \%$ であった が， $t$-BEN は分解されなかった.

文献

1) Hashimoto, S., Kawai, Y., Mutai, M.: Infection \& Immunity, 11, 1405 1406 (1975).

2) Rowland, I. R., Grasso, P.: Applied Microbiology, 29, 7〜12 (1975).

3) 伊藤誉志男, 谷村顕雄： 食衛誌. 12, 177〜184 (1971).

4) 高畠英伍, 吉村英敏編：“衛生化学新論” p. 86 87 (1980) 南山堂. 